\title{
A Debate on Transforming Local Governance in the UK: Is Partnership A Better Way?
}

\author{
Guang-Xu Wang \\ Department of Public Administration and Management \\ National University of Tainan, Tainan \\ Tel: 886(0)6213111 ext.954 Fax: 886(6)2144409Ｅ-mail: guangxu.wang@gmail.com
}

\begin{abstract}
In order to overcome financial crisis, it is an international tendency to have the shift from a traditional government to local governance. Tony Blair's New Labour Party came to power in 1997 committed to modernise a local government system to local governance via launching series of long-term action plans. This paper attempts to discuss the institutional transformation and the key policy in the government's modernisational agenda for local government, i.e. the local strategic partnerships (LSPs). Moreover, the most important aim of this paper is to explore three neglected disadvantages of local governance. However, the local governance mechanism is by no means always a positive experience and a double-sided knife. On the one hand, the advantage is the flexibility and efficiency in service delivery and participation; on the other hand, there is the possibility of an increase in collaborative cost, unbalanced power relationship between these agencies and fragmented accountability.
\end{abstract}

Keywords: Local governance, Collaborative management, Local Strategic Partnerships (LSPs), Network, Decentralisation

We want local governments to become more confident and more proactive, working with their citizens to create strong, prosperous communities which are ready to make most of opportunities of the $21^{\text {st }}$ century (Tony Blair, 2006(Note 1)

\section{Introduction}

For advanced countries, the role of local government has experienced major changes in the past 30 years. This is especially due to the government's fiscal crises and other flaws of inefficiency, as more public services and daily necessities originally belonging to the government are now relying on the private sectors or third party sectors to fulfil the needs of the citizens. Moreover, numerous international non-governmental organisations, such as the World Bank and the OECD, have promoted the ideas of decentralisation and local governance either in developed or developing countries to make public processes more efficient, to improve social service provision, to bring together citizens and their local authorities, to increase civil society participation in decision-making, and to reduce expenses (OECD, 1999; 2001; 2002).

There is no doubt that the UK has been one of the pioneers to facilitate the change of local governance mechanisms in the world-wild reform trend since 1980s. The change from traditional local government to a more complex network of agencies involved in "local governance" is more than a theory in the UK (Goss, 2001; John: 2001; Stoker, 2004; Wilson and Game, 2006). By 1997, the incoming Labour government integrated the Conservative Government's policy of the "Compulsory Competitive Tendering, ССТ" in the idea of new governance which concerned more about the inter-agency working or partnerships at local level (John, 2001; Goss, 2001; Skelcher, 2004). Recently, the latest progress of UK's local governance has been transferred to "Big Society but Small Government" launched by the Conservative-Liberal Democratic Government in 2010. The new programme, evidently, also attempts to put people power at the heart of government via encouraging participation and adhere the value of decentralisation. Based on these facts above, local government, private enterprises and non-profit organisations in the UK have built a coalition or so-called "public-private partnerships" (PPPs) and "cross-boundary work" in new governance theory's popular terms. (Note 2) It can be seen that local governance describes the way these agencies interact at local level and Rhodes (1997: 15) describes local governance as carried out through "self-organisation, inter-organisational networks".

Numerous attempts have been made (Goss, 2001; Stoker, 2004; Sullivan and Skelcher, 2002; Wilson and Game, 2006) to show the positive performance of the local governance mechanism in recent years, but little attention has been given to the negative impacts of a local governance regime. Goss (2001: 23) refers that the emergence of relationships of governance makes it clearer that we are in an era of multi-legitimacies which will bring new governing problems. Weber and Khademian's (2008) provocative essay indicate that typical hierarchical bureaucracy is also a barrier to cause "wicked problem" in information and knowledge sharing among multiple 
diverse and interdependent stakeholders. Sorenson and Torfing (2004: 22) acutely point out that the transformation tendency of decentralisation will face the challenge of imbalanced responsibilities and power among these stakeholders. It will undermine political competition and increase the problem that how actors can be regulated through processes of network governance. How such a coalition among public, private sectors and citizens influenced the structure of local governance, besides solving the problems of the government's failure and the enterprise's externalities, needs further analysis. If a new governance structure was really formed, does this new kind of structure support the supposition of new governance theory? Can we also suppose that by good governance, the local governments, private enterprises and citizens will construct an equilateral triangle in their power relationship, as outlined in the new governance theory?

Under the pressure of the government performance, the public agencies, especially the elected politicians, are keen to demonstrate their partnership credentials without the partnership failure. The paper attempts to examine the British local governance mechanism from the neglected point of view by reviewing the existing literatures. The historical legacy and institutional transformation are presented first, and the strategies of local governments to facilitate the collaborative partnerships by Tony Blair's New Labour Party will be introduced. After introducing institutional transition and policy instruments, section three will furnish three arguments against the local governance theory, which need to be taken in deep consideration.

\section{Historical Legacy and Institutional Transformation}

To understand the UK local governance, it is essential to grasp the basics of its historical development. Leach and Wilson (2002) observe that "from traditional welfare state to collaborative partnership with other agencies" is the most appropriate description of the institutional transformation of the UK local government since 1960s.

\subsection{The Operational Phase: 1965-81}

It is true that the UK government system has had its glorious tradition of welfare state in the recent centuries. This tradition also showed a similar mechanism at local governments in the UK in early 1970s. Under the central economic planning and management (Note 3), the local governments under the Labour Government included most functions (Note 4) to deal with people's needs, and were requested to be directly responsible for public services. Leach and Wilson (2002: 670) point out that the dominant principles of local authorities were self-sufficiency, professionalism and departmentalism. On the other hand, the most important mission of the local authority was to not only identify but also respond to public demand in order to maintain legitimacy so that profession-led departments and their committee chairs rarely felt the need for public involvement.

After World War II, the governments around the world suffered from increasing pressure in financial crises and the people's daily necessities, and the common consensus of a strong government and welfare state started to be challenged. In order to maintain the government operation and to satisfy the people, the central government had to spend more money on caring for poor people, and this led to a serious deadlock of economic depression. The professional and large local regime also had to face the throng of government failure and a few Conservative-controlled local authorities challenged the Labour Government's policy at that moment. The demand of a judicious decision let the Labour Government fail the election in 1979 while citizens thirsted for Margaret Thatcher to bring the good life back.

\subsection{The Transitional Phase: $1981-97$}

Since the 1980s, Western industrial countries faced a financial crisis and it was impossible for the Conservative Government of Margaret Thatcher and John Major to ignore the deadlock. To cope with the crisis, the central government cut public expenditures and transferred some public services to private sectors and non-profit organisations via possibly contracting out and privatization (Cheema and Ronedinelli, 2007). (Note 5) Thus, empowerment and public-private partnerships were emphasized and arose. Discussing the role transformation of local government during this period, scholars in public administration have two major perspectives: (1) The central government, facing financial pressure, transforms through decentralisation; (2) After financial decentralisation, local governments gain more power while facing more financial pressure, creating the need to form alliances with other resource providers, thus reorganizing the structure of local power (Stoker, 2004). This process of power re-organisation refers to the significant change "from local government to local governance" during this period (Goss, 2001).

There is no doubt that the Thatcher Government was the origin to launch into local governance and to embrace other agencies at local level. The Conservative government, especially in the period of Margaret Thatcher, viewed local authorities with considerable hostility, generally regarded them as inefficient, unresponsive and monopolistic bureaucracies (Wilson and Doig, 2000: 58), putted the New Right ideology into practice, and tried to bring the 
market competitive mechanism in the inefficient bureaucratic system to facilitate governments' performance. The Thatcher Government implemented a series of policy instruments such as privatization, contracting out, BOT (Note 6) and performance evaluation to reform the local governments in the UK. Moreover, during the period of so- called Thatcherism, the most important policy was that the first legislation - incorporating the principle of Compulsory Competitive Tendering (CCT) (Note 7) - was introduced in 1981.

In order to decrease the burden of the financial deficit of the Thatcher Government, the central government started to decentralise power and resources to strengthen the capabilities of local governments through the principle of Compulsory Competitive Tendering (CCT). From now on, empowerment and public-private partnerships at local level were emphasized and arose. Although local governments gained more autonomy to cope with the local affairs, it was also bearing more pressure when facing the challenges of performance and people's daily necessities. The difficult and arduous situation imposed the local governments to contract out their direct public service delivery responsibilities to indirect way of serving by private sectors.

During the changing period, the most important feature was emphasized more on the competitive principles in local governments and contract culture of service deliveries. The goal of local governments was to downsize their routines to other private agencies and make people who are regarded as customers under the New Right ideology to satisfy with the new public service style. These policy instruments which were advocated market as a means of overcoming inefficient bureaucratizes also became the important policy legacy of the reform under the New Labour (Geddes, 2006: 83).

\subsection{The Collaborative Phase: 1997 Onwards}

The most important feature of this period was the collaborative partnership which was based on the phenomenon of "network governance" and "hollowing out state" (Rhodes, 1994, 1996, 1997). In the past decade, decentralisation has become the fundamental value of government reform in the UK and there was to be no return to local authorities being nearly the monopolistic service providers (Wilson, 2005: 156). It can be seen that the erosion of local authorities as direct service providers did not seem to be suddenly or dramatically reversed and the incoming Labour government had to overcome the complex governing environment.

In order to overcome the fragmented pattern of local governance, Tony Blair started to scheme a whole reform picture to make local governments accommodate to the era of local governance - governing without government (Rhodes, 1996). Nevertheless, the New Labour Government's vision for local government, expressed in the so-called Blairism of "the Third Way" and then developed in the Green Paper Modernizing Local Government: Local Democracy and Community Leadership (DETR, 1998), was not a "clean break" with the pattern of changes introduced by Conservative predecessors but a new tactic to manage the collaborative relationship under the era of local governance. The modernization of local government was based on the democratic renewal agenda of the New Labour Party. The agenda indicated that the responsibility of the central government is to steer local authorities to make the partner relationship with other local agencies and use strategic managements to supervise the development of local area. The Local Government Act, passed in 2000, which is the practice of local governance, emphasized that local strategic partnerships (LSPs) are the tactics for local authorities to provide public services and to facilitate democratic participations. Most British scholars in public administration point out that the local authorities under the New Labour has not been the solo actor within local affairs, and interdepartmental, interorganisational coordination and the ability of diverse agencies to work together has become exceedingly important for these local authorities (Cheema and Rondinelli, 2000; Goss, 2001; Stoker, 2004). In addition, the Conservative-Liberal Democratic Government came to power in 2010, committed to introduce the "Big Society Programme" inheriting the spirit of partnership and decentralisation, to put more power and opportunity into people's hands and facilitate the collaborative governance network between local government, communities and citizens. Concluded above, that is the reason why the governing pattern of partnership under the ruling of New Labour was specified by the term of "local governance".

However, what exactly is local governance? Rhodes (1996: 652) points out that governance is popular but imprecise, but the common consensus is that governance involves working across boundaries within the public sector or between the public sector and private or voluntary sectors (Stoker, 2004). Furthermore, numerous scholars (Goss, 2001; Stoker, 2004; Rhodes, 1997; Skelcher, 2004; Sullivan and Skelcher, 2002; Wilson and Game, 2006) share the common view on three major characteristics of local governance: (1) It has a flexible local system and organisational structure arrangement; (2) Local government can autonomously choose the action process of sustainable development to establish a strategic cooperative partner relationship between the government, the private sectors and citizen organisations; (3) Local governance depends on a citizen-participation network corresponding to public affairs. In other words, scholars consider public and private sectors will help each other through joint 
participation during the process of public-private partnership or co-producing through the spirit of equality, so that finally the local governance reform will yield an equilateral triangle of power (see Figure 1).

Figure 1

The development of British local governance can be summarised in Table 1. The historical development of local governance mechanism in the UK can be summarized as from a "large and powerful government" to a "small and flexible" government. At local level, Stoker (2004) footnotes the institutional transformation faithfully in the term of "from local government to local governance" which has become the most important common consensus in the UK academic community.

Table 1

\section{Local Governance under New Labour: LSPs}

In the age of governance, the elected local government is just one of a multiple bodies involved in local service delivery. For many UK commentators, local governance theory is closely associated with the New Labour local government modernisation agenda (Stoker, 2004). LSPs are the most important policy instrument for Tony Blair's New Labour Party to put the idea of local governance into practice. LSPs exist in nearly all local areas in England and Wales, encouraging joint working,(Note 8) community involvement and preventing "solo working" (Note 9) with the general aim of ensuring resources are better located at a local level.

\subsection{The Nature of LSPS}

Partnership whose aims are to pursue the cooperative public services and create the better welfare provisions has become the most popular collaborative governing pattern in the UK last two decades. According to government guidance (DETR, 2001), a LSP is an umbrella partnership that brings together organisations from public, private, community and voluntary sector in a local area. The key objective of LSPs in government guidance is to improve the quality of life in a local area (DETR, 2001). The partnership governing mechanism mirrors the governance phenomenon which used to indicate the patterns of relations between interdependent actors who can not attain their goals by themselves but need the resources from other actors (Kickert, Klijn and Koppenjan, 1997: 6).

As mentioned above, local governance theory points out that collaborative partnership is an equilateral triangle. For the membership of the LSPs, the government guidance tells that local authorities are responsible for facilitating public sectors, community organisations and the local people, voluntary organisations and business to work together; and they are all significant in the alliance of a LSP (DETR, 2001: 7). The research of the University of Warwick et al. (2003) also points out that the average number of members in a LSP is 14.2. (Note 10) Moreover, LSPs are non-statutory and largely non-executive organisations, and the intention is that they operate at a level which enables strategic decisions to be taken yet is grassroots enough to allow direct community engagement.

In other words, LSPs can promote local democratic participations. They provide a point at which the host of individual partnerships in the area can be integrated and get involved. LSPs emerged autonomously in a number of localities, and the Local Government Association's New Commitment to Regeneration gave an added impetus to this process by sponsoring "pathfinder" local authorities to be actively built for leaders in public, business, community and voluntary sector (Sullivan and Skelcber, 2002). However, in England and Wales, LSPs are now being adopted by all local authorities as the mechanism by which the statutory duty of preparing a community strategy can be fulfilled.

To sum up, as Sullivan and Skelcber (2002) significant work indicates, there were almost 5,326 (Note 11) collaborative partnerships in the UK after the launching of LSPs. There is no doubt that LSPs has become the most important local regime which is closely associated with the idea of local governance in the UK.

\subsection{The Functions of LSPs}

LSPs are a major recent innovation in the pattern of local governance in England, resulting in a major process of local institution building in numerous localities (Aulakh, et al., 2002). In order to promote LSPs, the Department of the Environment, Transport and the Regions (DETR) announced the government guidance on LSPs in March 2001. The guidance indicates that LSPs are a wider project for the modernization agenda of public services under the ruling of New Labour (DETR, 2001). More specific information of the wide project is as arranged in Table 2

Table 2

There is no denying that the involvement of the community is a key aspect of the government's vision of LSPs and the policies of community strategies, public service agreement (PSA) and neighbourhood renewal are used to stimulate the people's life and slow down the gap between town and county by the improvement of economy, environment and social well-being of each area and contribute to achievement of sustainable development across the 
country. Although there normally cover a single local authority's area, but some have a sub-regional scale or bring together county and districts where there is two-tier local government. It also means that the function of LSPs not only engages key actors in the development of a vision for each area but also can contribute to the cross-boundaries or cross-sectors public affairs such as environmental preservation, public service delivery, safer communities, economic development and the operation of area rapid transit system (DCLG, 2007: 11). Furthermore, The New Labour Government has promoted the other long term plan "New Deal for Communities" to match up LSPs in order to sustain the LSPs in each local area and it means that the community-based collaborative partnership is developing gradually and is emphasized that the mechanism of LSPs should be formalized and continued regularly.

Although LSPs increase the operational complexity of the British local Governments, the collaborative mechanism obviously facilitates the interaction between these local agencies (Sullivan and Skelcher, 2002: 26). LSPs, based on the idea of partnership, have formed in many different kinds of operational pattern and shared these local agencies' resources and vision each other easier. The hallmark of effective governance is an openness and transparency in decision-making and a willingness not only to share information and resources but also to bear the responsibilities via cross-agency thematic working groups. Local authorities are required to show that their proposals are supported by the people, and need to work with other partners to deliver the LPSAs target through the agency of the LSPs (DERT, 2001). LSPs can thus be seen as an attempt to institute "local meta-governance" arrangements (Jones and Ward, 2002; Geddes, 2006) and represent an attempt to open up local governance to a wider range of local interests which better reflect the local priorities and needs.

According to the annual reports of Office of the Deputy Prime Minister, Department for Transport and Department for Communities and Local Government (2003, 2004, 2007), it can be seen that the governing culture of local areas has changed in the UK. Moreover, LSPs also have reached high performance in contributing to local inhabitants' needs. Interdependence is the essential feature of LSPs and the participators have to collaborate to increase local's autonomy and recuperate mutually in order to lead the most effectiveness of local governance. In spite of the fact that the emergence of new form of local governance, with local government becoming a lead agency in new networks of collaboration, it also has to consider more about the possible situation of the over-control complex processes of so-called wide-ranging changes in the new era.

\section{Debates on Local Governance: Partnership for Better Governance?}

Local governance theory expects all agencies who involve in the collaborative relationship to be good partners. The aim of this section is to discuss the three neglected disadvantages of the collaborative partnership.

\subsection{Collaboration is a Synonym of Coordinative Cost}

An effective and efficient LSP is not easily achieved. A variety of agencies with different interests and different degrees of commitment to the process have to be brought together. Each agency has its own way of working, its own structure, operational culture, and accountability. In order to stimulate a successful LSP, the local authorities must try to contact local agencies and build up a relationship first. The next difficulty will be to coordinate these local agencies to conclude a consensus and decrease the conflicts between different interests. Furthermore, the collaborative partnership is not a one-shot game and how to consolidate and maintain a long-term mechanism must also be considered. In general, the first problem of the collaborative partnerships is how consociating different private interests and maintain the public interests at the same time.

In the past, the organisational hierarchies were used to be organised the operational body of a government which included most functions to provide public services. The institutional design of hierarchical organisations attempts to decrease the communicative cost between different departments and increase efficiency in operation. As mentioned above, local governance, involved in multi-agencies, is a different governing structure which includes a large number of partners to work interdependently. One might ask whether a LSP can add value or is scary big number of the governing membership. Moreover, with large numbers a LSP can become a mass meeting, rather than a partnership in which all are fully involved in drawing up the strategy and equally committed to it (Stewart, 2003: 24). The first danger is that the LSP then become a talking shop or a meeting to rubber-stamp conclusion reached elsewhere.

It is worth stressing that the significant work, the 'optimal constitution' of Buchanan and Tullock (1962) indicates that decision-making cost is considerably related to the number of the policy makers (see Figure 2). In their model, the optimal constitution cost $(\mathrm{C}+\mathrm{D}$ cost) is divided into the external cost function (line $\mathrm{D}$ ) and the decision-making cost function (line C); and the optimal constitution cost depends on the adjustment of these two costs. In order to increase the democratic participation of decision making, the best way is to get more stakeholders involved in the decision-making process and build up the consensus of the majority. If more stakeholders are involved in the decision making process, the external cost will decrease while the decision-making cost will increase (point $\mathrm{L}$ ). 
(Note 12) Base on the idea of optimal constitution, a collaborative partnership is also the mechanism which attempts to decrease the external cost but increase decision making cost at the same time.

Figure 2

In conclusion, although partnership can overcome the limitations of separately run services in meeting the needs of some of the most vulnerable British society - children, older people, and those with mental health problems. There is, however, counter-argument in coordinative cost. As the Audit Commission (2005) points out, complex partnership working incurs costs. If partnerships mean spending too much time on discussing process issues instead of achieving their objectives, the costs can outweigh the benefit. It is of considerable importance that a collaborative partnership also means the fragmentation of authority which creates problems and opportunities for joint-through collaboration.

\subsection{Inequalities in the Power Relationships}

As noted previously, local governance theory assumes that the relationship between public and private sectors and citizens in service provisions and decision-making process is an equilateral triangle. There is no doubt that LSPs which are based on local governance theory have benefited the local development in the UK during the era of retrenchment. Although the idea of local governance has been popularly adopted, few scholars argue the negative situation of practice in the UK or other countries in the world. In the UK, the institutional legacy of welfare state and local democracy stimulates the promotion of LSPs (Goss, 2001; Stoker, 2004; Sullivan and Skelcher, 2002; Wilson and Game, 2006), but other countries might not have the same mature conditions to promote the equilateral triangle in power relationship.

Another theory, clientelism, or so-called patron-client theory, also concentrates on the relationship between multi-agencies (Note 13) at local level, arguing that the maintenance of relationships of exchange depends on the satisfaction of the actors toward each other and toward the expected return. If the expected return is not satisfied, the relationship will be terminated (Kaufman, 1974: 285). Under the analytical framework of clientelism, the relationship between patrons and clients is not equilateral, and Powell (1970) creates a principle definition for the exchange relationship of the clientelism system: (1) There is an asymmetric relationship between the patron and the client in rank, wealth and influence; (2) The formation and maintenance of the relationship is based on the reciprocal exchange principle; (3) The development and maintenance of the clientelism relationship rests heavily on face-to-face contact.

Using clientelism to explore the exchange relationship between local agencies in LSPs is helpful in clarifying the changes in local governance structure. First, although the environment of local governance is decentralising, there is no doubt that the only statutory organisation is the local authorities which control the crucial point of the local collaborative partnership's operation. Second, the private sectors, especially the large enterprises, have replaced the public sectors to become the provider of social service provision in numerous places, seeking also to establish a stable environment for capital accumulation. Many real cases show that those private sectors that are rich and have international capital flow seem to have the advantage in replacing the upper political structure as the patron in the local governance structure. (Note 14) The feature of the governing environment of local governance is fragmental between local agencies and the interdependent interaction is based on the exchange of power and resources (Rhodes 1997: 15). Although a large enterprise which has sufficient resources is good for providing service and local development, it is also possible that a too powerful business will destroy the balance of collaborative relationships and let local government and community become the victims of its commercial benefits (Yu and Wang, 2007). (Note 15)

In spite of the fact that the empirical cases cannot be found so far in the UK, it is true that the real world is not perfect as the prediction of local governance theory. The collaborative partnership structure is not the equilateral triangle structure expected by local governance theory, but rather an imbalance or vertical power relationship as proposed by capitalistic clientlism. Therefore, the dominant power of a LSP will depend on which actors control the main power and have capability to manipulate the process of governance.

\subsection{The Dilemma of Collaborative Action in Accountability}

Collaborative partnerships should be complex, dynamic and varied. Local authorities would not only lose the responsibility for services under the decentralising environment but also lose important levers of influence for leadership. Collaborative partnerships might cause a risky governance environment. Under the circumstance, how to evaluate the performance of collaborative partnerships is also a serious problem, and it is also obviously related to the challenge of accountability. It means that evaluators are operating in a dynamic environment among a range of stakeholders who may have very different views about the purpose and design of the evaluation and interpretation. 
As mentioned above, multi-agency partnerships can lead to more coordinative cost and operate with considerable interdependence of an authorizing body. But in the past, the traditional notions of accountability embodied in administrative law, with their emphasis on controlling the discretion exercised by government agencies, do not quite suffer (Salamon, 2002: 604). It can be seen that it is a more complex situation to fulfil the criterions of accountability in the temporal local governance environment.

In addition, the collaborative partnership, like LSPs, enables organisations to pass their responsibilities such as financial and service burdens towards other partners or the entire partnership, which is itself not clearly accountable and often less visible than the separate organisation that constitute it. This phenomenon can be explained easily by the game theory. The original game theory builds on the rational, self-interested actor, determining to maximize his material welfare regardless of the costs for others and focusing on situations in which individual incentives lead to collectively undesirable outcomes (Ostrom, 1990; Scholz, Berardo and Kile, 2008). The prediction of the game theory indicates significantly that it is very difficult to make the self-interested actors to collaborate together, and their rational preferences also lead to the collapse of the accountability mechanism. Mancur Olson's (1965: 2) basic argument is fairly simple: everybody prefers to take a free ride, but the consequence is that no one actually provides the necessary vehicle. If the actors in an LSP always act with their own preferences, it is possible that they might also try to be a free rider in service provision, and shirk their responsibilities and accountabilities to other partners.

To sum up, the aim of collaborative partnerships, especially the mechanism of LSPs, is to facilitate the interaction of resource and information exchange, share the responsibility, and stimulate the local democratic participation; but there are issues of the partnership's accountability. If, for understandable reasons, these accounting issues in multi-agency partnerships are difficult, accountability is necessarily weakened (Wilson and Game, 2006: 151). Although there is no evidence to prove the shirking behaviour in collaborative partnerships so far, in order to avoid governance failure, how to consolidate the accountability mechanism should be seriously considered as an ordeal to the leadership in local collaborative partnerships.

\section{Conclusion}

The Labour Government elected in 1997 pledged to modernise and transform the world of the UK local government, and it is clear that the performance of the reform is obviously positive. Stoker (1998: 26) points out that the new governance theory helps to provide a map or guide to the changing world of the governments, but the world is a little more complex than the official guidance suggested. Besides producing advantages, such as higher efficiency and higher potency, the role change among service deliverers has also brought problems never faced before under past bureaucratic systems of service delivery. Increasing coordinative cost between partners, unbalanced triangle power relationship in local governance and fragmented accountability are all neglected problems which might damage the performance of collaborative partnerships.

Certainly, local collaborative partnerships cause the fragmented formal authorities and create collaborative problems. As for government agencies today, collaborating, sharing resources, and working with the private sectors and NGOs has become the definition of modern day public service delivery (Gray et al., 2003). Problem-solving takes place in complex games and networks in which stakeholders behave strategically, guided by diverging or conflicting perceptions and rules (Kiekert, Koppenjan and Kinjn , 1997; Koppenjan and Kinjn, 2004). The challenge for the local governance mechanism is to recognise the constraints on central action imposed by the shift to self-organizing network, and to search for new tools for managing such uncertain network governing environments (Agranoff and Mcguire, 2003). Furthermore, the new UK government (Conservative-Liberal Democratic Government) launched the "Big Society" programme aiming to create a climate that empowers local people and communities, building a big society that will "take power away from politicians and give it to people". It is obvious that the new proposal also follows the logic of local governance theory to bring other parties, especially local people and communities, to involve in governance activities. In spite of the fact that local collaborative partnerships are still ongoing not only in the UK but also other places in the world, the local authorities have to be ready to work with the imperfect rather than to expect partnerships of perfection.

In particular, it should be noted that the real cases which can be used to prove the negative points of local governance theory could not be found to support the arguments of the three neglected points and further work could be done for more evidence-based deliberations. Although this paper lacks the negative cases, there is no doubt that the central problem of collaborative partnerships can be concluded as how to reconcile the desire for the flexible governance mechanism with the demands of a strong public-interested, democratic and accountably operational relationship.

\section{References}

Audit Commission. (2005). Governing Partnerships: Bridging the Accountability Gap [WWW document]. London: 
Audit

Commission.

URL

http://www.audit-commission.gov.uk/Products/NATIONAL-REPORT/1CDA0FEF-E610-463c-B3F3-220F607B1A2 C/GoverningPartnerships26Oct05REP.pdf > [accessed 15 May 2008].

Agranoff, R. and McGuire, M. (2003). Collaborative Public Management: New Strategies for Local Governments. Washington, D.C.: Georgetown University Press.

Buchanan, J. M. and Tullock, G (1962). The Calculus of Consent, Logical Foundations of Constitutional Democracy. Ann Arbor: The University of Michigan Press.

Cheema, G. S. and Ronedinelli, D. A. (2007). 'From government decentralisation to decentralised governance'. in Cheema, G. S. and Ronedinelli, D. A. (eds.) Decentralising Governance: Emerging Concepts and Practices. Washington, D.C.: Brookings Institution Press. pp. 1-20.

DCLG (Department for Communities and Local Government). (2006). Strong and Prosperous Communities: the Local Government White Paper. London: DCLG. URL http://www.communities.gov.uk/publications/localgovernment/strongprosperous > [accessed 15 May 2008].

DCLG (Department for Communities and Local Government). (2007). National Evaluation of Local Strategic Partnerships: Report on the 2006 Survey of all English LSPs [WWW document]. London: DCLG. URL < http://www.communities.gov.uk/publications/localgovernment/englishlsps > [accessed 15 May 2008].

DCLG (Department for Communities and Local Government). (2007). Planning Together: Local Strategic Partnerships (LSPs) and Spatial Planning: A Practical Guide [WWW document]. London: DCLG. URL < http://www.communities.gov.uk/publications/localgovernment/planningtogetherlocal > [accessed 15 May 2008].

Geddes, M. (2006). Partnership and the limits to local governance in England: institutionalist analysis and neoliberalism. International Journal of Urban and Regional Research 30(1): 76-97.

DETR (Department of the Environment, Transport and the Regions). (1998). Modernizing Local Government: Local Democracy and Community Leadership. London: DERT.

DETR (Department of the Environment, Transport and the Regions). (2001). Local Strategic Partnerships: Government Guidance [WWW document]. London: DETR. URL < http://www.communities.gov.uk/publications/localgovernment/localstrategicpartnerships2 $>\quad[$ accessed 15 May 2008].

Goss, S. (2001). Making Local Governance Work: Network, Relationships and the Management of Change. Basingstoke, Hampshire: Palgrave.

Gray, A. et al. (2003). Collaboration in Public Services. New Brunswick and London: Transaction Publishers.

John, P. (2001). Local governance in Western Europe. Thousabd Oaks: Sage Publications.

Kaufman, R. R. (1974). The patron-client concept and macro-politics and problems. Comparative Studies in Society and History 16 (3): 284-308.

Kickert, W. J. M., Klijn, Erik-Hans and Koppenjan, J. F. M. (1997). 'Introduction: a management perspective on policy networks'. In Kickert, W. J. M., Klijn, Erik-Hans and Koppenjan, J. F. M. (eds.) Managing Complex Network: Strategies for the Public Sector. London: Sage Publication. pp. 1-13.

Koppenjan, J. F. M. and Klijn, Erik-Hans. (2004). Managing Uncertainties in Networks: A Network Approach to Problem Solving and Decision Making. New York: Routledge.

Leach, S. and Wilson, D. (2002). Rethinking local political leadership. Public Administration 80 (4): 665-689.

OECD (1999). Managing Accountability in Intergovernmental Partnership. Paris: OECD.

. (2001). Local Partnerships for Better Governance. Paris: OECD.

(2002). Distributed Public Governance: Agencies, Authorities and other Government Bodies. Paris: OECD.

Olson, M. (1965). The Logic of Collective Action, Cambridge, MA: Harvard University Press.

Ostrom, E. (1990). Governing the Commons: the Evolution of Institutions for Collaborative Action, New York: Cambridge University Press.

Powell, J. D. (1970). Peasant society and clientelist politics. American Political Science Review, 64 (2): 411-425.

Rhodes, R. A. W. (1994). The hollowing out of the state. Political Quarterly, 65: 138-151.

. (1996). The new governance: governing without government. Political Studies. 44(4): 652-667. 
(1997). Understanding Governance, Buckingham: Open University Press.

Salamon, L. M. (2002). 'The tools approach and the new governance: conclusion and implications'. in Salamon, L. M. (ed.) The Tools of Government: A Guide to the New Governance. Oxford, New York: Oxford University Press. pp. 600-610.

Scholz, J., Berardo, R. and Kile, B. (2008). Do network solve collaborative action problems? credibility, search and collaboration. The Journal of Politics. 70 (2): 393-406.

Skelcher, C. (2004). 'The new governance of communities'. in Stoker, G. and Wilson, D. (eds.) British Local Government into the $21^{\text {st }}$ Century. Basingstoke: Macmillian. pp. 25-42.

Sorenson, E. and Torfing, J. (2004). Making Governance Networks Democratic, Working Paper, Centre for Democratic Network Governance. Roskilde University.

Stewart, J. (2003). Modernising British Local Government: An Assessment of Labour's Reform Programmeme. Basingstoke, Hampshire; New York: Palgrave Macmillan.

Stoker, G. (1998). Governance as theory: five propositions. International Social Science Journal. 155: 17-28. Macmillan.

(2004). Transforming Local Governance: from Thatcherism to New Labour. Basingstoke: Palgrave

Sullivan H. and Skelcber, C. (2002) Working across Boundaries: Collaboration in Public Services. Hampshire: Palgrave.

Tabarrok, A. (2006). The Calculus of Consent [WWW PowerPoint]. URL < http://mason.gmu.edu/ atabarro/CalcofConsent\%20ch6.ppt\#260,5,Choose the Decision Rule to Minimize Total (C+D) Costs $>$ [accessed 20 May 2008].

University of Warwick, University of the West of England, Office for Public Management and Liverpool John Moores University. (2003). Evaluation of Local Strategic Partnerships: Report of a survey of all English LSPs [WWW document]. Report for the Office of the Deputy Prime Minister and Department of Transport, London. URL $<$ http://www.communities.gov.uk/publications/localgovernment/evaluationlocal > [accessed 15 May 2008].

Weber, E., \& Khademian, A. (2008). Wicked problems, knowledge challenges, and collaborative capacity builders in network settings. Public Administration Review, 68(2), 334-349.

Wilson, D. (2005). 'The United Kingdom: an increasing differentiated polity?' in B. Denters and Rose, L. E. (eds.) Comparing Local Governance: Trends and Developments. Basingstoke: Macmillian. pp. 155-173.

Wilson, J. and Doig A. (2000). Local Government in the United Kingdom $\left(3^{\text {rd }}\right)$. Basingstoke: Macmillian.

Wilson, D. and Game C. (2006). Local Government in the United Kingdom $\left(4^{\text {th }}\right)$. Basingstoke: Macmillian.

Yu, I. W. and Wang, G. X. (2007). New governance or new clientlism: the case of local governance transition in Taiwan. Paper was invited to present in the $27^{\text {th }}$ International Congress of Administrative Sciences, 9-14 July 2007 in Abu Dhabi, United Arab Emirates.

\section{Notes}

Note 1. The quotation is cited from Tony Blair's foreword in the white paper of Strong and Prosperous Communities (DCLG, 2006).

Note 2. Actually, the concept "public private partnerships" was originally rooted in public management theory which indicates that private sectors are more effective and efficient than public sectors in public services. The new governance theory follows the concept and adjusts the meaning of public private partnerships. This theory more emphasizes on the collaborative relationship among stakeholders in policy domains and service delivery network.

Note 3. It can be seen that the keynesian economy which considers the role of a government to be strong and large.

Note 4 . The functions are so-called welfare state regime which means that the most service expenditure and delivery are provided by the government directly.

Note 5. These policies are the practices of the New Right ideology emphasized by Thatcher, the so called Thatcherism.

Note 6. Built-Operate and Transfer, it is one of the main policy tools of the British Government to stimulate efficiency and performance in 1980s. BOT means that private sectors have chance to get the permission to involve and invest public infrastructure and transfer the property right of the infrastructure to governments after an operative period of time. 
Note 7. The CCT passed in 1981 was the main policy instrument of local government reform under the Thatcher Government.

Note 8. According to the survey of DCLG report, there were almost 211 LSPs in the UK in 2006 (DCLG, 2007).

Note 9. It means that different agencies which share aims working in isolation.

Note 10. According to the report, the average number of local authority membership in a LSP is 4, other public sector is 5.7, private sector is 1.5 and voluntary and community sector is 3.0, totally is 14.2 (University of Warwick et al., 2003).

Note 11. This survey was conducted in 1999, and the number reflected the situation from 1997 and 1999.

Note 12. The model attempts to explain which point is the optimal point (the optimal participation number is K) in decision-making process. Although increasing the members in decision-making process can facilitate the democratic participation, it still increases the coordinative cost at the same time (shift to point L). It should be seriously considered the partner number in a LSP.

Note 13. The relationship especially concentrates on the interaction between state and civil society.

Note 14.There are some famous cases in contracting out the public service deliveries such as Group 4 Security Service (G4S), Centre for British Teachers (CfBT) and Hospital Trust in the UK. Some of them cause numerous problems in public service. For instance, the matters in dispute in health service can be seen on MRSA.

Note 15. The best case is the NIMBY effect (Not in my back yard). NIMBY means that the government promotes the necessary developing policy with the collaboration of large businesses in a local area and the policy might benefit for all people in general. Moreover, these large businesses usually not only cause undesirable externalities for the local residents but also let the government be captured by these businesses' benefits.

Table 1. The Development History of Local Governance

\begin{tabular}{|l|l|l|l|}
\hline Phase & The Operational Phase & The Transitional Phase & The Collaborative Phase \\
\hline Period & $1965-81$ & $1981-97$ & $1997-$ \\
\hline Ruling Party & Labour Party & Conservative Party & $\begin{array}{l}\text { New Labour (1997-2010), } \\
\text { Conservative-Liberal Democratic } \\
\text { Government }\end{array}$ \\
\hline $\begin{array}{l}\text { Policy } \\
\text { Philosophy }\end{array}$ & $\begin{array}{l}\text { Politics in Left, large } \\
\text { government, the central } \\
\text { economic planning and } \\
\text { management }\end{array}$ & $\begin{array}{l}\text { New Right (neoliberalism) in politics, small } \\
\text { government, new public management. The } \\
\text { governing philosophy of this period can } \\
\text { be concluded in the term of Thatcherism }\end{array}$ & $\begin{array}{l}\text { The third way, partnership and collaboration } \\
\text { with other agencies, new governance. The } \\
\text { governing philosophy of this period can be } \\
\text { concluded in the term of Blairism. }\end{array}$ \\
\hline $\begin{array}{l}\text { The regime of } \\
\text { local government }\end{array}$ & $\begin{array}{l}\text { Government-centered } \\
\text { political management, } \\
\text { traditional public } \\
\text { administrative state }\end{array}$ & $\begin{array}{l}\text { Contracting out and sharing power with } \\
\text { private sectors, the public private } \\
\text { partnership under new public management }\end{array}$ & $\begin{array}{l}\text { Making partnership relationship with other } \\
\text { agencies at local level, the public private } \\
\text { partnership under new governance theory }\end{array}$ \\
\hline Policy tool & $\begin{array}{l}\text { Providing people's daily } \\
\text { necessities and maintain } \\
\text { the legitimacy of } \\
\text { governments }\end{array}$ & $\begin{array}{l}\text { Bringing market mechanism as a means } \\
\text { into bureaucracy to improve the efficiency } \\
\text { of governments }\end{array}$ & $\begin{array}{l}\text { Collaborating with other local agencies to } \\
\text { improve the burden of fiscal crises and solve } \\
\text { the social problems and people's need } \\
\text { Let local people involved in the local regime } \\
\text { and increase the democratic participations. }\end{array}$ \\
\hline Goals & $\begin{array}{l}\text { Direct } \\
\text { Public service } \\
\text { style }\end{array}$ & Indirect (by private sectors) & Indirect (by collaborating with multi- sectors) \\
\hline
\end{tabular}

Source: created by the author 
Table 2. The Programmemes promoting LSPs

\begin{tabular}{|c|c|c|}
\hline Programmeme & Objectives & Why working together is important \\
\hline $\begin{array}{l}\text { Community strategies: new duty on local } \\
\text { authorities in England and Wales under } \\
\text { Local Government Act } 2000 \text { to prepare } \\
\text { community strategies. }\end{array}$ & $\begin{array}{l}\text { To improve the economic, social and } \\
\text { environment well-being of each area and its } \\
\text { inhabitants, and contribute to the } \\
\text { achievement of sustainable development in } \\
\text { the UK. }\end{array}$ & $\begin{array}{l}\text { Local authorities have many of the responsibilities } \\
\text { and powers needed to bring about improvements in } \\
\text { their communities. But other public services, local } \\
\text { people, business, and the voluntary and community } \\
\text { sectors also need to be given opportunities to } \\
\text { contribute. }\end{array}$ \\
\hline $\begin{array}{l}\text { Rationalization of the many current } \\
\text { separate partnerships, plan and initiatives. } \\
\text { The steps central government took to set } \\
\text { out in summer } 2001 \text {. }\end{array}$ & $\begin{array}{l}\text { To integrate existing plans and initiatives so } \\
\text { that it is easier to deliver improvements in } \\
\text { health, education crime and so on; reduce } \\
\text { duplication and unnecessary bureaucracy; } \\
\text { and make it easier for partners, including } \\
\text { those outside the statutory sector, to get } \\
\text { involved. }\end{array}$ & $\begin{array}{l}\text { Complex problems need concerted and co-ordinated } \\
\text { action. Partners need to ensure they work effectively } \\
\text { together across all of their activities. They need to be } \\
\text { able to do so in ways that avoid duplication and } \\
\text { wasted resources. }\end{array}$ \\
\hline $\begin{array}{l}\text { Local Public Service Agreements (LPSAs): } \\
\text { piloted with } 20 \text { authorities in 2001/02. With } \\
130 \text { other "top tier" authorities on a } \\
\text { voluntary basis on the two years following } \\
2001 / 02 \text {. }\end{array}$ & $\begin{array}{l}\text { To allow local authorities to commit } \\
\text { themselves to delivering key national and } \\
\text { local priorities in return for agreed } \\
\text { flexibilities, pump-priming funding, and } \\
\text { financial rewards if they meet their targets. }\end{array}$ & $\begin{array}{l}\text { Local authorities will need to show that their } \\
\text { proposals are supported by local people and other } \\
\text { local partners. Joint working will almost always be } \\
\text { needed to deliver local PSA targets. }\end{array}$ \\
\hline $\begin{array}{l}\text { Neighbourhood renewal: National Strategy } \\
\text { Action Plan published January } 2001 .\end{array}$ & $\begin{array}{l}\text { To narrow the gap between the most deprived } \\
\text { neighbourhoods and the rest of the country, } \\
\text { with common goals of lower unemployment } \\
\text { and crime, and better health, education, } \\
\text { housing and physical environment. }\end{array}$ & $\begin{array}{l}\text { Effective neighbour renewal depends on services } \\
\text { working together to plan and deliver concerned } \\
\text { improvements in public services. Local people, } \\
\text { business and the voluntary sector all need to have } \\
\text { opportunities to contribute. }\end{array}$ \\
\hline
\end{tabular}

Source: DETR (2001: 5)

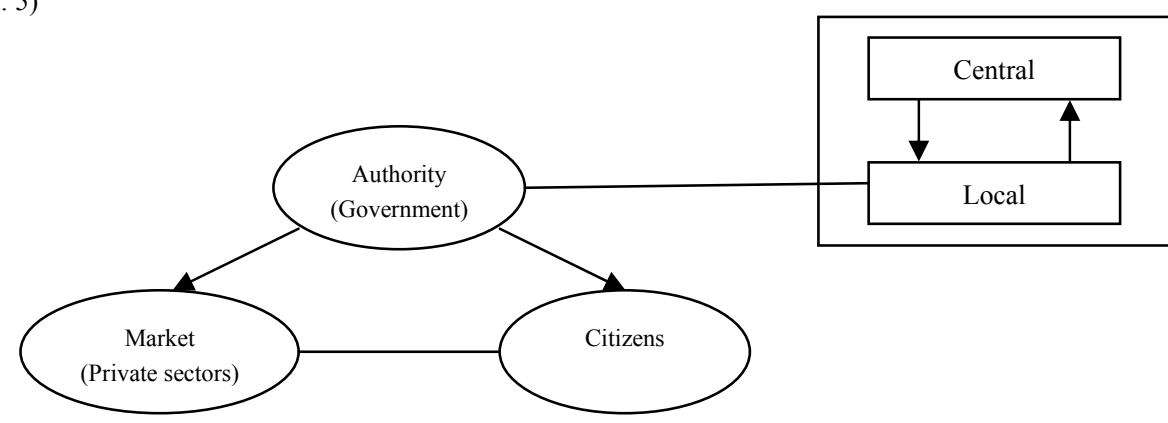

Source: created by the author

Figure 1. The Structure of Local Governance

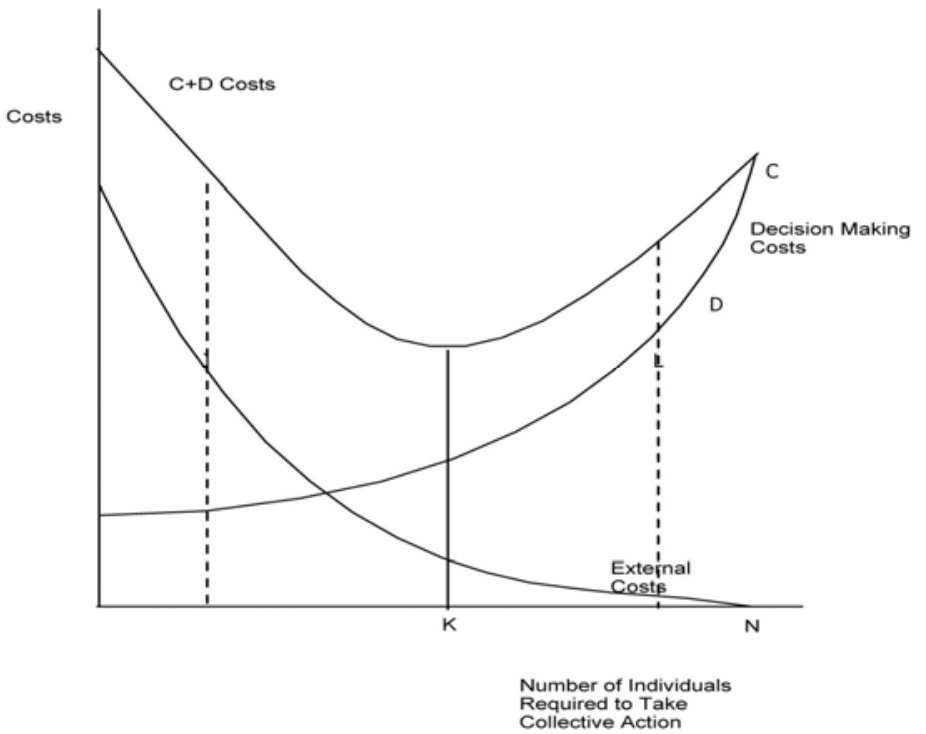

Figure 2. The Optimal Constitution Model 